\title{
Why Agile Logistics Information System Infrastructure (ALISI) Matters for Innovative Services (ISERV) and Competitiveness (COMP)
}

\author{
Darjat Sudrajat ${ }^{1}$; Nadia Kris Sigit ${ }^{2}$; Hargian Dianto Andjagi ${ }^{3}$ \\ Business Management Program \\ BINUS Business School-Undergraduate Program, Bina Nusantara University \\ Bekasi, Indonesia 11480 \\ darjat.sudrajat@binus.edu ${ }^{1}$; nadia.sigit@binus.ac.id ${ }^{2}$; hargian.andjagi@binus.ac.id ${ }^{3}$
}

\begin{abstract}
Information system infrastructure is one of strategic resources for developing firm competitiveness but whether or not it has a direct impact on the firm competitiveness or must be through innovative services. This research intended to answer the question. The research used a causal method, cross-sectional survey, probability sampling and SEM-PLS program in processing data. The sample size consisted of 75 Logistics Service Providers (LSP) as members of Indonesian Logistics and Forwarder Association (ILFA) in Jakarta (Jabodetabek area). This research found that the agile logistics information system infrastructure (ALISI) must be modified first into innovative services (ISERV) in order to had more positive and significant effect on Firm Competitiveness (COMP).
\end{abstract}

Keywords: Logistics Service Provider (LSP), Agile Logistics Information System Infrastructure (ALISI), Innovative Services (ISERV), Competitiveness (COMP)

\section{Introduction}

National logistics performance is one of the importance aspect to enhance national competitiveness. Whereas, both national logistics performance and competitiveness are still a problem in Indonesia [1,2]. Indonesia's position for both indicators is still below from Singapore, Thailand and Malaysia. The national logistics performance is measured based on customs, infrastructure, international shipment, logistics competency, tracking and tracing, and timeliness. Whereas national competitiveness is measured by basic requirements ( institutions, infrastructure, macroeconomic environment, health and primary education), efficiency enhancers (higher education and training, goods market efficiency, labor market efficiency, financial market development, technologies readiness, market size), innovation and sophistication (business sophistication and innovation)

Based on government's blueprint of logistics regulation, one of key drivers to improve the condition is logistics service industry [3]. They are various types of companies that provide both partial and integrated logistics services [4]. According to the Association (ALFI) about $50 \%$ of the Indonesian Logistics Service Companies have poor performance so that they cannot compete with their competitors particularly foreign companies.

Theoretically, some researchers stated that information system had effect on firm innovation and competitiveness [5,6]. The higher firm innovation the higher their competitiveness $[7,8]$; developing new technology is at the heart of strategic competitiveness 
[9]. In this research, therefore, was set a model encompass the relationships of the three variables namely agile information system infrastructure, innovative services and firm competitiveness. Conceptually, the innovative services mediate effect of agile information system infrastructure on firm competitiveness. The main purpose of the research is to examine the innovative services as mediator variable for effect of agile information system infrastructure on firm competitiveness. Therefore, the research problem is "does the agile information system infrastructure has effect on firm competitiveness pass through innovative services?"

\section{Literature Review}

Strategic management constitute full set of commitments, decisions and actions were required by companies in achieving their strategic competitiveness [9]. The definition was used as grand theory in this research. Dynamic capabilities is one of strategic management perspectives. It is company's ability to modify and leverage its resource in gaining and sustaining competitive advantage [10]. According to [11], there are three group of strategic management schools, namely boundary, dynamic capability, and configurational schools. The dynamic capabilities school was used in this research in approaching its problems. The school stated that strategic management is a collective learning process intended to develop unique abilities that difficult to be imitated. The company's resources and capabilities, therefore, will be better basis for formulating strategy. This school is an inside-out rather than an outside-in view. It meant that the firm's performance as a function of the firm's ability in utilizing its resources. In connection with that, as middle theory of the research used resource-based view and dynamic capabilities perspective. The resource-based view (RBV) refers to a model, perspective and theory $[9,10,12,13]$ stated that resources and capabilities are key to the company's success to achieve competitive advantage and excellent performance. Dynamic capability constituted a model, ability, capacity or process $[10,12,13,14]$ that integrate, construct, and reconfigure external and internal competencies to cope with change of environments. It also comprise sensing, seizing and transforming processes that create and modify routine operational activities [15]; which create, extend, or modify the firm's resources [16]. According to [17], dynamic capabilities can be analyzed through three elements, namely innovative, absorptive, and adaptive capabilities.

Agile Information System Infrastructure constitute hardware, software, and telecommunications equipment that combined to provide foundation to support the organization's goals [18]. In the future, the companies' success depend on their abilities to fulfill their partners, suppliers, and customers any time in any geographic location. An agile information system infrastructure has seven (7) indicators comprise availability, accessibility, reliability, maintainability, portability, scalability and usability. Availability is the time frames when the system is running; Accessibility is defined what a user can access, view, or perform when operating a system in varying levels; Reliability ensures a system is functioning correctly and providing accurate information; Maintainability constitute how quickly a system can transform to support environmental changes; Portability is the ability of an application to operate on different devices or software platforms, such as different operating systems; Scalability describes how well a system can scale up or adapt to the increased demands of growth; Usability refers to the degree to which a system is easy to learn and efficient and satisfying to use [18]. 
Innovation is the process of idea generation, technology development, manufacturing and marketing of a new product and/or services [19,20,21]. Innovation constitute the key element for firm's sustainability [19,20,21]. The dimensions of innovation encompasses visibility (the innovation tend to product or process innovation), radicality (the innovation tend to radical or incremental innovation), disruptility (the innovation enhance or destroy existing competence), modularity (the innovation tend to architectural or modular) [20]. Product innovations refers to the outputs newness of an organization both goods and services; Process innovations refers to the way an organization carried out its business, such as techniques of producing or marketing goods or services; Radical innovation is an innovation that is realy new and different from previous solutions; Incremental innovation refers to innovation that makes a relatively minor change from existing practices; The innovation enhance the company's previous competence if it builds on the company's existing knowledge base; The innovation destroy the company's previous competence if the technology does not build on the company's existing competencies or renders them obsolete; Modular innovation is an innovation to one or more components or processes that does not significantly affect the overall configuration of the system; Architectural innovation is an innovation that changes the overall design of a system or the way its components interact with each other [20].

Firm competitiveness refers to firm's ability in using innovative and productive resources and capabilities to increase output, maintain and gain market share, offer goods and services, respond and win competition, and create customer value [22,23]. The competitiveness indicates a firm's ability in designing, producing, and marketing a product or service better than its competitors. The firm's competitiveness can be evaluated through several factors such as financial, price, quality, and technology [24,25]. In this research, the competitiveness is defined as ability of logistics service providers (LSP) in using their resources to support competition and create value for customers. The dimensions of competitiveness consist of financial strength, customer value, and skills.

\section{Research Method}

This research used quantitative or causal method [26]. This research's analysis unit was the organization, whereas the observation unit was the company's leader (manager or director). Data were collected by using questionnaires (Likert scale) and probability sampling (simple random sampling). The respondents consisted of 75 logistics service providers (LSP) that registered as members of Indonesia Logistics and Forwarder Association (ILFA) in the Jakarta (Jabodetabek) region. The research's data was processed by using SEM-PLS program.

The research consisted of three latent variables: Agile Logistics Information System Infrastructure (ALISI), Innovative Services (ISERV), and Competitiveness (COMP). The Agile Logistics Information System Infrastructure (ALISI) had seven indicators (accessibility, availability, mantainability, portability, reliability, scalability, usability); Innovative Services (ISERV) had four indicators (product, process, position, and paradigm), and competitiveness (COMP) had three indicators (financial, cuatomer value, skills). The hypotheses of this research are as follows;

- $\mathrm{H}_{1}$ : Agile Logistics Information System Infrastructure (ALISI) has effect on Innovative Services (ISERV).

- $\mathrm{H}_{2}$ : Innovative Services (ISERV) has effect on Firm Competitiveness (COMP)

- $\mathrm{H}_{3}$ : Agile Logistics Information System Infrastructure (ALISI) has effect on Firm Competitiveness (COMP). 
- $\mathrm{H}_{4}$ : Agile Logistics Information System Infrastructure (ALISI) has effect on Firm Competitiveness (COMP) pass through Innovative Services (ISERV).

\section{Results and Discussion}

Based on data processing, the data was valid and reliable. In connection with that, the data could be further processed by SEM-PLS to test the structural model (inner model). The results of the test (inner model) showed that variation of Competitiveness (COMP) could be explained by Agile Logistics Information System Infrastructure (ALISI) and Innovative Services (ISERV) by $64,3 \%$ and the rest $(35,7 \%)$ was explained by other variables that were not examined in the research.

The results of hypotheses tests showed that Agile Logistics Information System Infrastructure (ALISI) had positive and significant effect on Innovative Services (ISERV); Innovative Services (ISERV) had positive and significant effect on Competitiveness (COMP); Agile Logistics Information System Infrastructure (ALISI) had positive and significant effect on Competitiveness (COMP); Innovative Services (ISERV) mediated significantly the effect of Agile Logistics Information System Infrastructure (ALISI) on Competitiveness (COMP) but it constitute a partial mediation because its direct effect had significant effect. The effect coefficients among the latent variables are shown in Figure 1.

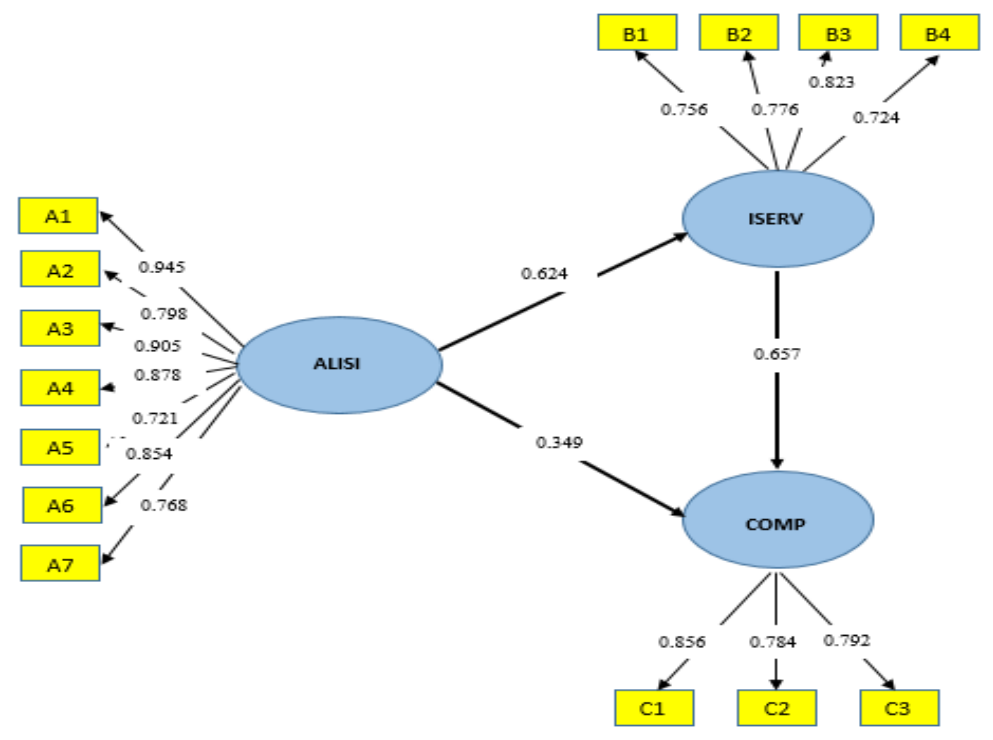

Figure 1. PLS Model (Algorithm) 
Based on the figure 1, the first hypothesis test showed that Agile Logistics Information System Infrastructure (ALISI) had positive and significant effect on Innovative Services (ISERV). The result emphasized that resource-based view (RBV) theory was effective explain the research's model. It showed that Agile Logistics Information System Infrastructure (ALISI) as one of strategic resources and it will able to be the importance resource for a good competitiveness. It meant also that the Agile Logistics Information System Infrastructure (ALISI) can strengthen other resources in shaping a unique bundle of resources so that it has a significant effect on firm competitiveness.

The second test showed that Innovative Services (ISERV) had positive and significant effect on Competitiveness (COMP). The result indicated that dynamic capabilities (DC) theory was effective in explaining the research's model. It was based on Wang and Ahmed (2007) that innovative capability is one of elements of dynamic capabilities. Agile information system infrastructure (AISI) as one of resources should be changed or modified into capabilites so that it has a significant impact on firm competitiveness. Sustainable competitive advantage only can be achieved if the firms were able to create and develop dynamic capabilities. In this case, agile logistics information system infrastructure (ALISI) must be developed and modified into dynamic capabilities so that the logistics service providers (LSP) will be able to explore logistics service business opportunities, develop new logistics services and share new logistics knowledges and experiences.

The third test showed that Agile Logistics Information System Infrastructure (ALISI) had positive and significant effect on Firm Competitiveness (COMP). The result showed that agile logistics information system infrastructure (ALISI) has to create and develop innovative services (ISERV) to enhance their competitiveness. In connection with that, in line with Rothaermel (2017) that the logistics service providers (LSP) must be able to change its internal resource base as the external environment changes. Indonesian logistics service providers (LSP) are facing deregulation, globalization, technological change and demographic shifts, so that today's dynamic markets are the rule rather than the exception. As a consequency, the firms (LSP) have to create, deploy, modify and reconfigure their resources (ALISI) so they can provide value to customers and/or lower costs in a dynamic environment. The result meant that competitive advantage was not derive from static resource or market advantages but from a dynamic reconfiguration of a LSP's resource base.

The fourth test showed that Agile Logistics Information System Infrastructure (ALISI) had positive and significant effect on Competitiveness (COMP) pass through Innovative Services (ISERV). It was also showed that Innovative Services (ISERV) mediated in partial the effect of Agile Information System Infrastructure (AISI) on Competitiveness (COMP). The result indicated that Indonesian logistics service providers (LSP) must be able to change and modify their agile logistics information system (ALISI) into Innovative Services (ISERV) so that they can enhance their competitiveness. It meant also that Innovative Services (ISERV) was not the only one of mediator variable in enhancing Competitiveness (COMP) of logistics service provider (LSP) in Indonesia but also there were some other mediator variables for the effect of Agile Logistics Information System Infrastructure (ALISI) on Competitiveness (COMP). Whereas the managerial implications showed that the logistics service provider (LSP) in Indonesia should develop Agile Logistics Information System Infrastructure (ALISI) particularly ability in providing information system infrastructure what a user can access, view, or perform when operating a system in varying levels in order to encourage LSP's Innovative Services (ISERV). Besides the effect, the companies should also prioritize to improve financial strength (working capital) in order to enhancing their competitiveness. 


\section{Conclusion}

The Agile Logistics Information System Infrastructure (ALISI) was importance for Logistics Service Providers (LSP) due to it able to enhance their Innovative Services (ISERV) and Firm Competitiveness (COMP). It would has higher effect if it was modified first pass through Innovative Services (ISERV). The Agile Logistics Information System Infrastrukture (ALISI), therefore, could encourage the Logistics Service Providers (LSP) in providing information system infrastructure that support their change program. In connection with that, the dynamic capabilities (DC) theory was more effective in explaining the research's model than resource-based view (RBV) theory. Theoretically, the Innovative Services (ISERV) mediated in partial the effect of Agile Logistics Information System Infrastructure (ALISI) on Firm Competitiveness (COMP). Practically, they should better prioritize accessibility of Agile Logistics Information System Infrastructure (ALISI), visibility of innovative services and strong working capital to enhance their competitiveness. One of limitations of the research was only used one of resources (ALISI), for further research could use other resources so that strengthening its results.

\section{References}

[1] World Bank. Logistics Performance Index 2018. Available from: http://lpi.worldbank.org, 2018

[2] World Economic Forum. Global Competitive Index 2018-2019. Available from: ww.weforum.org/ reports/ global-competitiveness-report-2018-2019

[3] Peraturan Presiden No. 26. tentang Cetak Biru Pengembangan Sistem Logistik Nasional (Sislognas), 2012

[4] J. Mangan and C. Lalwani, Global Logistics and Supply Chain Management. Third Edition. UK: John Wiley \& Sons Ltd., 2017

[5] P. Neirotti and D. Pesce, ICT-Based Innovation and Its Competitive Outcome: The Role of Information Intensity, European Journal of Innovation Management, https://doi.org/10.1108/EJIM-02-2018-0039, Emerald Publishing Limited, 2018

[6] M. Pomffyova and L. Bartkova. Take Advantage of Information Systems to increase Competitiveness in SMEs, Procedia-Social and Behavioral Sciences, Vol. 220, p.p. 346-354, Elsevier, 2016

[7] H. Tambade, R.K. Singh and S. Modgil, Identification and Evaluation of Determinants of Competitiveness in the Indian Auto-Component Industry, Benchmarking: An International Journal, https://doi.org/10.1108/BIJ-09-2017-0260, Emerald Publishing Limited, 2018

[8] O. Ungerman, J. Dedkova and K. Gurinova, The Impact of Marketing Innovation on the Competitiveness of Enterprises in the Context of Industry 4.0, Journal of Competitivenss, Vol. 10, Issue 2, pp. 132-148, DOI: 10.7441/joc.2018.02.09, 2018

[9] M.A. Hitt, R.D. Ireland and R.E. Hoskisson, Strategic Management: Competitiveness \& Globalization, Concepts and Cases, $12^{\text {th }}$ Edition. USA: Sout-Western, Cengage Learning, 2017

[10] F.T. Rothaermel, Strategic Management, Third Edition, New York: McGraw-Hill/Irwin, 2017

[11] H. W. Volberda and A. T. Elfring, Rethinking Strategy, London: SAGE Publications Ltd., 2001

[12] G. G. Dess, G. T. Lumpkin, A. B. Eisner and G. McNamara, Strategic Management: Text and Cases, Seventh Edition, New York: McGraw-Hill/Irwin, 2014

[13] R. M. Grant and J. Jordan, Foundations of Strategy, Second Edition, UK: John Wiley \& Sons, Ltd., 2015 
[14] G. G. Inan and U. S. Bititci, Understanding Organizational capabilities and Dynamic Capabilities in the Context of Micro Enterprises: A Research Agenda, Procedia-Social and Behavioral Sciences, Vol. 210, pp. 310-319, 2015

[15] D. J. Teece, The Foundations of Enterprise Performance: Dynamic and Ordinary Capabilities in an (Economic) Theory of Firms, The Academy of Management Perspectives, Vol. 28, No. 4, pp. 328-352, 2014

[16] C. E. Helfat and M. A. Peteraf, Understanding Dynamic Capabilitis: Progress Along A Developmental Path, Strategic Organization-Sage, 2009

[17] C. L. Wang and P. K. Ahmed, Dynamic Capabilities: A Review and Research Agenda, The International Journal of Management Reviews, 9(1): 31-51, 2007

[18] P. Baltzan, Information Systems. Fourth Edition. New York: McGraw-Hill/Irwin, 2018

[19] P. Trott, Innovation Management and New Product Development. Sixth Edition, Harlow: Pearson Education Limited, 2017

[20] M.A. Schilling, Strategic Management of Technological Innovation. Fifth Edition, New York: McGraw-Hill Education, 2017

[21] S. Ottosson, Developing and Managing Innovation in a Fast Changing and Complex World: Benefiting from Dynamic Principles, Switzerland: Springer International Publishing AG, 2019

[22] C. Altomonte, T. Aquilante and G.I.P. Ottaviano, The Triggers of Competitiveness: The EFIGE Cross-Country Report, Belgium: Bruegel Blueprint Series, Volume XVII, 2012

[23] S. Kantha, Building Firm-Level Trade Competitiveness in Emerging Economies, Geneva: ICTSD-WEF, 2015

[24] D. Depperu and D. Cerrato, Analyzing International Competitiveness at the Firm Level: Concepts and Measures, Universita Cattolica del Sacro Cuore, Working Paper No. 32, 2005

[25] E. Akben-Selcuk, Factors Affecting Firm Competitiveness: Evidence from an Emerging Market, International Journal of Financial Studies, doi:10.3390/ijfs4020009, 2016

[26] Sekaran, U. dan Bougie, R. (2016) Research Methods for Business: A Skill-Building Approach. Seventh Edition. United Kingdom: John Wiley \& Sons Ltd. 